\title{
ILL'S MEALYBUG, FERRISIA GILLI, CAN TRANSMIT GRAPEVINE LEAFROLL- ASSOCIATED VIRUS-3 AFTER A 24-HOUR ACQUISITION TIME
}

Taylor Jones, Mizuho Nita*

Alson H. Smith Jr. Agricultural Research and Extension Center, School of Plant and Environmental Sciences, Virginia Polytechnic Institute and State University, USA.

\section{ART I C L E I N F O}

\section{Article history}

Received: March 19, 2020

Revised: May 24, 2020

Accepted: August 15, 2020

\section{Keywords}

Grapevine leafroll-

associated virus-3

GLRaV-3

Ferrisia gilli

virus acquisition

virus transmission

\section{A B S T R A C T}

Grapevine leafroll disease (GLD) is a virus disease present in all grapevine-growing regions of the world. Mealybugs and scale insects have been reported as vectors of some grapevine leafroll-associated viruses belongs to the ampeloviruses (family Closteroviridae) in particular with grapevine leafroll-associated virus-1 (GLRaV-1) and GLRaV-3. Both grape (Pseudococcus maritimus) and Gill's mealybugs are commonly present in Virginia vineyards, but we have limited information on acquisition and transmission of GLRaV-3 by Gill's mealybug (Ferrisia Gilli). We conducted acquisition and transmission assays in the greenhouse to examine the threshold for shorter acquisition time of GLRaV-3 with $F$. gilli. Approximately $67 \%$ and $58 \%$ rates of GLRaV3 acquisition by $F$. gilli following 24 and 48 hours, respectively, of feeding period were documented. F. gilli first instars fed on a GLRaV-3-positive grapevine for 24 and 48 hours successfully transmitted GLRaV-3 to healthy grapevines after 24 hours of feeding/transmission time. The quick acquisition demonstrated in this study could be one of the factors that promoted the rapid expansion of GLRaV-3-infected vines in vineyards documented in previous studies.

Corresponding Author: Mizuho Nita

Email: nita24@vt.edu

(C) The Author(s) 2020.

\section{INTRODUCTION}

Grapevine leafroll disease (GLD) is a virus disease present in all grapevine-growing regions of the world (Naidu et al., 2014). In severely infected vineyards, direct yield loss can be as high as $40 \%$, and indirect crop losses can be caused in the form of decreased wine quality due to uneven ripening of berries, reduced sugar levels, changes in $\mathrm{pH}$ and $\mathrm{TA}$, and insufficient development of berry color (Cabaleiro et al., 1999; Wolpert and Vilas, 1992).

Mealybugs and scale insects [order Hemiptera, suborder Sternorrhyncha, superfamily Coccoidea, families Coccidea (scale) and Pseudococcidae (soft scale/mealybug), have been reported as vectors of grapevine-infecting viruses. The ampeloviruses (family Closteroviridae), grapevine leafroll associated virus-1 (GLRaV-1) and GLRaV-3, which are known as causal agents of GLD, are known to be transmitted by these vectors (Tsai et al., 2010). GLRaV-3 is more widespread across grapevine-growing regions than other GLRaVs (Naidu et al., 2014).

The first mealybug documented to successfully transmit GLRaV-3 to a healthy grapevine in a laboratory setting was Planococcus ficus (vine mealybug) (Engelbrecht and Kasdorf, 1990). Recent studies have demonstrated that the grape (Pseudococcus maritimus), longtailed (Pseudococcus longispinus), citrophilus (Pseudococcus calceolariae), citrus (Planococcus citri), and obscure 
(Pseudococcus viburni) mealybugs) are all capable of transmitting GLRaV-3 in semi-persistent manner (Cabaleiro and Segura, 1997; Golino et al., 2002; Petersen and Charles, 1997; Tsai et al., 2008; Tsai et al., 2010).

Both Pseudococcus maritimus and the Gill's mealybugs (Ferrisia gilli) were commonly found in Virginia vineyards (Jones and Nita, 2019; Jones et al., 2015). The grape mealybug is associated with GLRaV-3 and has a wide host range, including grapevines, figs, apples, and citrus crops (Wistrom et al., 2016). Gill's mealybug is a hypothesized native to the southeastern United States and has been described as a pest of pistachios, almonds, and grapes in California (Wunderlich et al., 2013). A study by Wistrom et al. (2016) demonstrated that $F$. gilli can transmit GLRaV-3, but not GLRaV-1, -2, and -4LV.

In our previous studies, we documented a widespread of GLRaV-3 among Virginia vineyards (Jones et al., 2015) and a very rapid (up to $185 \%$ increase per year) spread of GLRaV-3-positive grapevines in a vineyard infested with both F. gilli and P. maritimus (Jones and Nita, 2016). However, information on $F$. gilli concerning the transmission of GLRaV-3 is limited, particularly their ability to transmit GLRaV-3 with short acquisition time (e.g., less than 48 hours). The rate of virus acquisition by a vector insect can affect the rate of infection, and thus, the management options (Madden et al., 2000). The objective of this study is to examine the effect of shorter acquisition time on the ability of $F$. gilli to transmit GLRaV-3 to healthy grapevines. The information will help us understand the effectiveness of GLRaV-3 transmission by F. gilli in the field.

\section{MATERIALS AND METHODS}

GLRaV-3 detection from mealybugs and grapevines

Mealybug nucleic acid extraction was conducted with the QIAGEN DNeasy Blood and Tissue kit following the manufacturer's instruction. Nucleotide extraction from grapevines was conducted as described in Jones et al. 2015 and Rowhani et al. 2000. The detection of GLRaV-3 from these extracts was using a one-tube one-step RTPCR method (hereafter referred to as the LR3 RT-PCR) (Jones et al., 2015; Rowhani et al., 2000).

\section{Grapevine preparation}

Grapevines used in the study were harvested from a section of a 'Cabernet franc' vineyard at the AHS AREC, Winchester, Virginia, USA (latitude 39.112873, longitude 78.284048). Vines were tested for GLRaV-3 in early
August and again in late September of 2014 and validated as GLRaV-3 free. A total of 100 cuttings were taken in February 2015 from these GLRaV-3-tested vines, to propagate in 1.5-gallon pots $(20 \mathrm{~cm}$ in diameters (both top and bottom), and $21 \mathrm{~cm}$ in height). In addition, canes from GLRaV-3-positive Cabernet franc vines in another vineyard were used to create 50 propagated vines in 1.5gallon pots. All vines used in this study were trained to single shoots to ensure that mealybugs to feed on a specific area of the plant, since grapevine viruses are not evenly distributed throughout all shoots. Vines were sprayed with potassium bicarbonate (Kaligreen applied at $3.4 \mathrm{~kg} / \mathrm{ha}$, Toagosei Co., LTD, Tokyo, Japan) to manage powdery mildew. Three ultra-fine-mesh cages $(1.83 \mathrm{~m} \mathrm{x}$ $1.83 \mathrm{~m} \times 1.83 \mathrm{~m}$ in dimension, BioQuip Products Inc., Rancho Dominguez, CA) were placed in a greenhouse to avoid contact with other insects. Hereafter, we refer to these cages as insect cages. Both GLRaV-3-negative and positive vines were re-tested with the LR3 RT-PCR one day before the experiment to confirm the absence and presence of GLRaV-3, respectively.

\section{Ferrisia gilli preparation}

Colonies of $F$. gilli were started with 54 adult female $F$. gilli collected from a vineyard in Orange County, Virginia (latitude 38.1670391, longitude -78.2616859) in May 2015., Mealybugs were gently transferred to sprouted potatoes using a fine-point paintbrush from vines in the field for transportation. In the greenhouse, mealybugs were gently moved to a GLRaV-3-negative Cabernet franc vine in an insect cage for rearing.

\section{Validation of the lack of transovarial passing of GLRaV-3 by $F$. gilli}

Prior to the experiment, a study was conducted to validate the viruliferous nature of $F$. gilli with respect to GLRaV-3. A total of eleven adult females were fed on a GLRaV-3positive Cabernet franc vine for several days, and eleven first instars born from these females were tested for GLRaV-3 as soon as they emerge. Nine of eleven adult females were positive for GLRaV-3. However, all eleven first instars were negative for GLRaV-3, indicating the lack of transovarial passing of GLRaV-3 with F. gilli. Since other mealybug species transmit other Amperoviruses in noncirculative, semi-persistent manner, this result was expected (Douglas and Krüger, 2008; Petersen and Charles, 1997). In addition, the species of these instars was confirmed as F. gilli using a previously published 
vineyard mealybug multiplex PCR assay (Cooper et al., 2011; Jones et al., 2015).

\section{GLRaV-3 acquisition assay with $\boldsymbol{F}$. gilli}

A total of $72 F$. gilli first instars reared on GLRaV-3negative vines were placed onto a GLRaV-3-positive vine and allowed to feed for 1, 2, 6, 12, 24, and 48 hours. At the end of each acquisition time, 12 instars were sampled and immediately tested for GLRaV-3. The experiment was conducted in May 2015. A threeparameter logistic regression model was fit to the data using JMP Pro (ver. 15, SAS Institute, Cary, NC, USA) to describe the relationship between feeding time and the rate of acquisition.

\section{GLRaV-3 transmission assay with $F$. gilli}

A total of $60 \mathrm{~F}$. gilli first instars from a GLRaV-3-negative vine in an insect cage were placed onto the GLRaV-3positive vine in a separate insect cage and allowed to feed 1, 2, 6, 12, 24, and 48 hours. Then transferred to GLRaV-3-negative vines in another insect cage to fed for 24 hours. There were two GLRaV-3-negative vines per each time group, and each vine received five mealybugs. In addition, ten first instars that were fed on two GLRaV3-negative vines to serve as the negative control. The experiment was conducted from June to October 2015.
After the 24-hour transmission times had expired, mealybugs were removed from the vines, placed into 0.5-ml tubes containing 95\% ethanol, and stored at $20^{\circ} \mathrm{C}$, then subjected to RNA extraction and the LR3 RTPCR described above. In addition, all instars used in the acquisition and transmission assays were subjected to species confirmation using the vineyard mealybug multiplex PCR assay (Cooper et al., 2011; Jones et al., 2015). Five petioles were arbitrarily collected at 75 and 135 days after feeding then subjected to the LR3 RT-PCR (Rowhani et al., 2000).

\section{RESULTS}

\section{GLRaV-3 acquisition assay with $F$. gilli}

The presence of GLRaV-3 was confirmed with one, eight, and seven out of $12 \mathrm{~F}$. gilli instars for the acquisition time of 12, 24, and 48 hours, respectively (Figure 1). The logistic model showed a good fit to the data with $R^{2}=$ 0.992. Although the sample size was small, these results demonstrated $F$. gilli was able to acquire GLRaV-3 after 12 hours of feeding, with an approximately $67 \%$ and $58 \%$ rate of acquisition per mealybug after 24 hours and 48 hours, respectively, of the feeding period. The negative check vines which were fed with $F$. gilli that were never fed on GLRaV-3-positive grapevine remained GLRaV-3-negative.

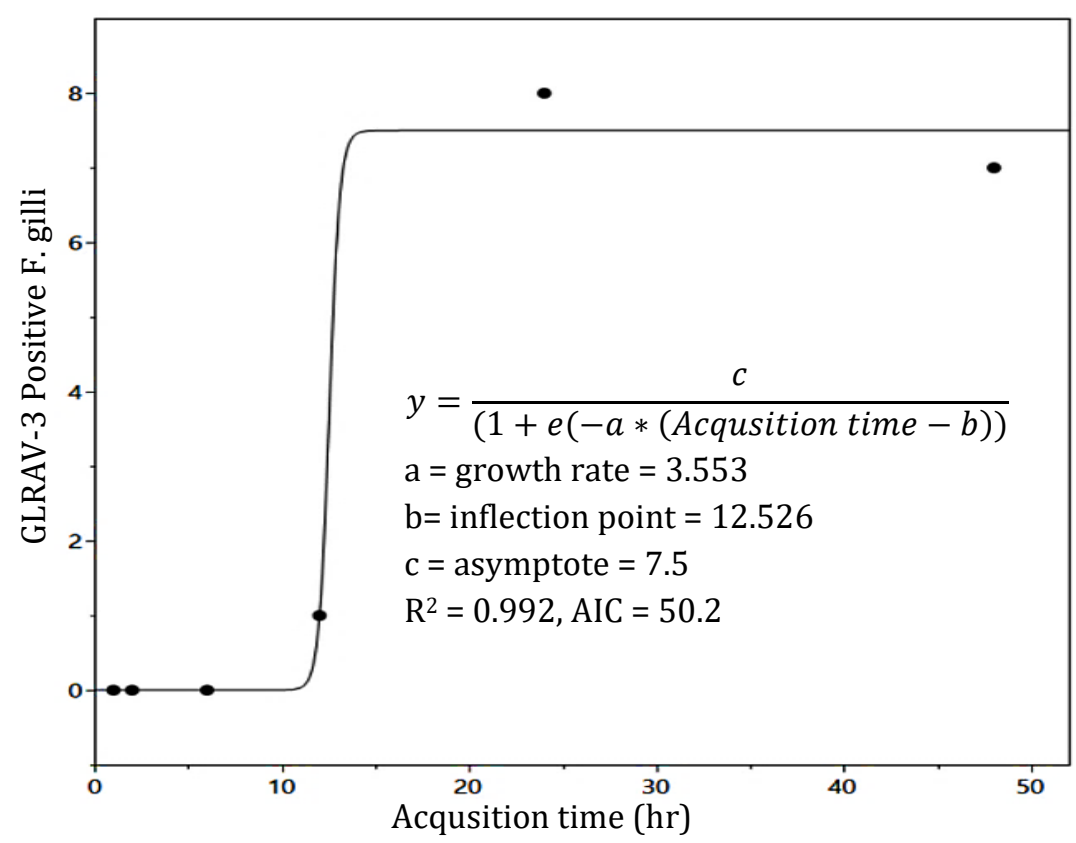

Figure 1. Number of GLRaV-3-positive F. gilli at 1-, 2-, 6-, 12-, and 48-hour acquisition time. The LR3 RT-PCR was conducted immediately after the end of each acquisition time (Rowhani et al. 2000). A green line shows a result of three parameter logistic model. The equation, parameters, $R^{2}$, and AIC (Akaike's Index of Criterion for the model fit) values are shown in the figure (JMP Pro ver. 15, SAS Institute). 


\section{GLRaV-3 transmission assay with $F$. gilli}

When the LR3 RT-PCR was conducted after 24-hour feeding/transmission time, one, seven, and six out of ten first instars, for 12-, 24-, and 48-hour acquisition feeding, respectively, were positive with GLRaV-3 (Table 1). At 75 days after transmission feeding, three vines were positive for GLRaV-3. One vine with a 24-hour acquisition feeding period and two vines with a 48-hour acquisition feeding period were GLRaV-3-positive. The negative check vines remained free of GLRaV-3. The result did not change at the second test on the same vines at 135 days after transmission feeding. The transmission efficiency based on Swallow (1985) is 0.03 . all instars used in the assay were confirmed as F. gilli.

Table 2. Numbers of GLRaV-3-positive grapevines after 75- and 135-day post-transmission feeding and F. gilli immediately after feeding/transmission time.

\begin{tabular}{ccccccc}
\hline \multirow{2}{*}{ Days after feeding } & \multicolumn{7}{c}{ Acquisition time (in hours) } \\
\cline { 2 - 7 } & 1 & 2 & 6 & 12 & 24 & 48 \\
\hline 75 & 0 & 0 & 0 & 0 & 1 & 2 \\
135 & 0 & 0 & 0 & 0 & 1 & 2 \\
Number of GLRaV-3-positive F. gilli ${ }^{b}$ & 0 & 0 & 0 & 1 & 7 & 6
\end{tabular}

a. For each acquisition time, two GLRaV-3-negative Cabernet franc vines were used. For each vine, five F. gilli first instars were placed. The same vines were assessed at 75- and 135-day after feeding.

b. Number of GLRaV-3-positive F. gilli out of ten individuals per acquisition time. The LR3 RT-PCR (Rowhani et al. 2000) was conducted immediately after transmission feeding (i.e., at the end of transmission time).

\section{DISCUSSION}

An approximately $67 \%$ rate of virus acquisition by $F$. gilli following 24 hours of feeding period was documented, and results from 48 hours of feeding did not differ greatly (58\%). Our results suggested although $F$. gilli was able to acquire GLRaV-3 after 12 hours of feeding, the rate of acquisition was meager $(1 / 12$ or $8.3 \%)$. The transmission assay used the same set of feeding times to acquire GLRaV-3 from an infected vine, and the combined rate of acquisition with a 24 and 48-hour feeding period was $68.1 \%$, and $59.1 \%$, respectively. A study by Wistrom et al. (2016) tested acquisition time of 48 and 96 hours, and reported after 48 hours, 64\% of $F$ gilli instars were able to acquire GLRaV-3. Our assays examined shorter acquisition times from 1 to 48 hours, and the mean rate of acquisition at 24 hours were numerically higher than that of 48 hours, and similar to the rate at 48 hours of feeding reported by Wistrom et al. (2016). Thus, F. gilli instars are more likely to acquire GLRaV-3 after 24 hours.

The vine mealybug, Planococcus ficus, is considered to be the most efficient at the transmission of GLRaV-3, and it can successfully acquire the virus after 1 hour of plantfeeding with the success rate steadily increasing up to the maximum of around $60-70 \%$ with 24 hours of feeding (Tsai et al., 2008). Our results showed F. gilli was not able to acquire GLRaV-3 with less than 24 hours of feeding, suggesting that the maximum rate of acquisition between $F$. gilli and P. ficus can be similar, but the time required for the acquisition is probably longer with $F$. gilli. In our study, trans-ovarial passing of GLRaV-3 was not found in F. gilli. A study on P. ficus also found the lack of GLRaV-3 in the first instars (Tsai et al., 2008).

The results of our transmission assay supported the semi-persistent nature of mealybug transmission of closteroviruses (Martelli et al., 2002). F. gilli instars fed on GLRaV-3-positive grapevine for 24 hours could transmit GLRaV-3 to the healthy vine after 24 hours of feeding, and we were able to detect GLRaV-3 from F. gilli after the 24-hour transmission time period. The transmission efficiency of 0.03 (Swallow, 1985) was less than what Wistrom et al. (2016) reported, which was 0.085 . With vine mealybugs ( $P$. ficus), the transmission efficiency of GLRaV-3 was 0.11 to 0.18 (Tsai et al., 2008). However, our sample size was too small to develop a solid conclusion. A recent study with P. maritimus, which is another commonly found mealybug species in Virginia, used a one-week inoculation period and reported a $65 \%$ transmission rate $\left(0^{\prime}\right.$ Hearn and Walsh, 2020).

Gill's mealybugs are reported to have two in-season generations in California, where they overwinter as second and third instars under bark along the cordon and trunks (Wunderlich et al., 2013). The first instars, which were used in this study, appear in June and then late-August/early-September in California. First instars 
can be disseminated by their own mobility, wind, and other causes; therefore, considered as the most efficient phase of transmission (Petersen and Charles, 1997). This study demonstrated that first instars of $F$. gilli's can acquire GLRaV-3 in 24 hours and transmit GLRaV-3 to the healthy grapevines. This relatively short acquiring time could be one of factors of a very rapid spread of GLRaV-3-positive vines documented in our previous study (Jones and Nita, 2016). In the same study, we documented the effectiveness of an insecticide spirotetramat in reducing number of mealybugs, which was a mix population of $F$. gilli and P. maritimus, with two field trials. However, a study by O'Hearn and Walsh (2020) indicated that even with the application of spirotetramat, P. maritimus was able to transmit GLRaV3 with a $40 \%$ transmission rate, which is very alarming. With its wide host ranges and ability to transmit GLRaV3 , vineyard managers need to be aware of the presence of $F$. gilli and take actions to help manage this pest. In addition, the use of clean (virus-tested) plant materials has to be incorporated into Grape Leafroll Disease management in the field (Jones and Nita, 2019; Maliogka et al., 2015).

\section{ACKNOWLEDGMENT}

We thank the Virginia Wine Board for providing funding support in 2009-2015.

\section{REFERENCES}

Cabaleiro, C. and A. Segura. 1997. Field transmission of grapevine leafroll associated virus 3 (GLRaV-3) by the mealybug Planococcus citri. Plant disease, 81: 283-87.

Cabaleiro, C., A. Segura and J. J. Garcia-Berrios. 1999. Effects of grapevine leafroll-associated virus 3 on the physiology and must of Vitis vinifera L. cv. Albarino following contamination in the field. American Journal of Enology Viticulture, 50: 4044.

Cooper, M. L., K. M. Daane, M. C. Middleton, R. Sforza, V. M. Walton, D. B. Walsh, T. Zaviezo and R. P. P. Almeida. 2011. Development of a multiplex PCR for identification of vineyard mealybugs. Environmental Entomology, 40: 1595-603.

Douglas, N. and K. Krüger. 2008. Transmission efficiency of grapevine leafroll-associated virus 3 (GLRaV-3) by the mealybugs Planococcus ficus and Pseudococcus longispinus (Hemiptera:
Pseudococcidae). European Journal of Plant Pathology, 122: 207-12.

Engelbrecht, D. J. and G. G. F. Kasdorf. 1990. Transmission of grapevine leafroll disease and associated closteroviruses by the vine mealybug, Planococcus ficus. Phytophylactica, 22: 341-46.

Golino, D. A., S. T. Sim, R. Gill and A. Rowhani. 2002. California mealybugs can spread grapevine leafroll disease. California Agriculture, 56: 196201.

Jones, T. and M. Nita. 2019. A survey of Virginia vineyards revealed high incidences of grapevine rupestris stem pitting-associated virus, grapevine red blotch virus, and two mealybug species. Plant Health Progress, 20: 207-14.

Jones, T. J. and M. Nita. 2016. Spatio-temporal association of GLRaV-3-infected grapevines, and effect of insecticidal treatments on mealybug populations in Virginia vineyards. European Journal of Plant Pathology, 145: 885-900.

Jones, T. J., N. A. Rayapati and M. Nita. 2015. Occurrence of grapevine leafroll associated virus-2, -3 and grapevine fleck virus in Virginia, USA, and factors affecting virus infected vines. European Journal of Plant Pathology, 142: 209-22.

Madden, L. V., M. J. Jeger and F. van den Bosch. 2000. A theoretical assessment of the effects of vectorvirus transmission mechanism on plant virus disease epidemics. Phytopathology, 90: 576-94.

Maliogka, V. I., G. P. Martelli, M. Fuchs and N. I. Katis. 2015. Control of viruses infecting grapevine. In, Advances in Virus Research. Elsevier.

Martelli, G. P., A. A. Agranovsky, M. Bar-Joseph, D. Boscia, T. Candresse, R. H. A. Coutts, V. V. Dolja, B. W. Falk, D. Gonsalves and W. Jelkmann. 2002. The family Closteroviridae revised. Archives of virology, 147: 2039-44.

Naidu, R., A. Rowhani, M. Fuchs, D. Golino and G. P. Martelli. 2014. Grapevine leafroll: A complex viral disease affecting a high-value fruit crop. Plant disease, 98: 1172-85.

O'Hearn, J. S. and D. B. Walsh. 2020. Effectiveness of imidacloprid, spirotetramat, and flupyradifurone to prevent spread of GLRaV-3 by grape mealybug, Pseudococcus maritimus (Hemiptera: Pseudococcidae). Journal of Plant Diseases Protection, 127: 805-09.

Petersen, C. L. and J. G. Charles. 1997. Transmission of 
grapevine leafroll-associated closteroviruses by Pseudococcus longispinus and P. calceolariae. Plant Pathology, 46: 509-15.

Rowhani, A., L. Biardi, R. Johnson, P. Saldarelli, Y. P. Zhang, J. Chin and M. Green. 2000. Simplified sample preparation method and one-tube RT-PCR for grapevine viruses Proceedings of XIII International Council for the Study of Viruses, Virus-Like Diseases of the Grapevine. Adelaide, South Australia.

Swallow, W. H. 1985. Group testing for estimating infection rates and probabilities of disease transmission. Phytopathology, 75: 882.

Tsai, C.-W., A. Rowhani, D. A. Golino, K. M. Daane and R. P. P. Almeida. 2010. Mealybug transmission of grapevine leafroll viruses: An analysis of virusvector specificity. Phytopathology, 100: 830-34.

Tsai, C. W., J. Chau, L. Fernandez, D. Bosco, K. M. Daane and R. P. P. Almeida. 2008. Transmission of grapevine leafroll-associated virus 3 by the vine mealybug (Planococcus ficus). Phytopathology, 98: 1093-98.

Wistrom, C. M., G. K. Blaisdell, L. R. Wunderlich, R. P. P. Almeida and K. M. Daane. 2016. Ferrisia gilli (Hemiptera: Pseudococcidae) transmits grapevine leafroll-associated viruses. Journal of Economic Entomology, 109: 1519-23.

Wolpert, J. A. and E. P. Vilas. 1992. Effect of mild leafroll disease on growth, yield, and fruit maturity indices of Riesling and Zinfandel. American Journal of Enology Viticulture, 43: 367-69.

Wunderlich, L. R., M. L. Cooper and K. M. Daane. 2013. Seasonal biology of Ferrisia gilli (Hemiptera: Pseudococcidae) in California sierra foothill vineyards. Journal of Economic Entomology, 106: 1716-25.

\section{CONFLICT OF INTEREST}

Mizuho Nita and Taylor Jones declare that we do not have any conflicts of interest..

\section{AUTHORS CONTRIBUTIONS}

Both authors contributed to experiments, data collection, data analysis, writing, and editing of this manuscript.

Publisher's note: EScience Press remains neutral with regard to jurisdictional claims in published maps and institutional affiliations.

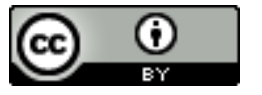

Open Access This article is licensed under a Creative Commons Attribution 4.0 International License, which permits use, sharing, adaptation, distribution and reproduction in any medium or format, as long as you give appropriate credit to the original author(s) and the source, provide a link to the Creative Commons license and indicate if changes were made. The images or other third-party material in this article are included in the article's Creative Commons license, unless indicated otherwise in a credit line to the material. If material is not included in the article's Creative Commons license and your intended use is not permitted by statutory regulation or exceeds the permitted use, you will need to obtain permission directly from the copyright holder. To view a copy of this license, visit http://creativecommons.org/licenses/by/4.0/. 